\title{
Bridging Instruction, Research and Community Involvement - Health, Environment Awareness Lecture Caravan - San Beda College Manila, Philippines
}

\author{
Liwayway H. Acero
}

\begin{abstract}
The Health, Environment Awareness Lecture Caravan (HEALC) of the Department of Natural Sciences-San Beda College Manila, Philippines is under the College of Arts and Sciences of San Beda College. The HEALC team is composed of the professors in the Department, served as lecturers and experts both in instruction and research output dissemination on Health and Environment aspect; invited experts from Project- NOAH (Nationwide Operational Assessment of Hazards) and NDRRMC (Nationwide Disaster Risk Reduction Management Council) enhanced lectures on environmental issues; fourth year BS Human Biology students shared their theses results in the community, the executive board of Kapisanang Agham ng San Beda organized and facilitate the conduct of the lecture/seminar and the Institutional Community Involvement Center (ICIC) of San Beda College. This study categorized the activities done by HEALC team based on trilogy function of the College. It analyzed participants' answers on the helpfulness of the lectures and identified possible community-based researches in partner communities of ICIC. A structured questionnaire was used to gather the perception of the participants on the helpfulness of the lectures done. It was analyzed using frequency and percentages. The HEALC proved to bridge the trilogy function of the college mandated by the Commission on Higher Education (CHED). The expertise of professors, students in the Department, increased the awareness and help people in the partner communities in Health and environment aspect as attested by their responses. Flyers in local dialect (Tagalog version) help people to fully understand the lectures. The HEALC team was able to identify and generate possible community-based researches as suggested by the participants.
\end{abstract}

Index Terms-Health, environment, research, community involvement.

\section{INTRODUCTION}

Colleges in the Philippines are mandated by the Commission on Higher Education to perform trilogy function; instruction, research and extension or community involvement or outreach activity. CHED mandate the interplay of the three functions of higher education institution, namely research, instruction, and community extension. The importance of research in education cannot be taken for granted aside from the fact that it is one of the criteria of evaluation among the different key areas in quality assurance [1]. It is, therefore, imperative that the faculty of Higher Education Institutions be required to engage in research

Manuscript received August 29 2016; revised October 30, 2016.

Liwayway H. Acero is with the Department of Natural Sciences, San Beda College, Manila, Philippines (e-mail: lilyacero1@yahoo.com). activities, be actively involved, and put the research findings to use effectively. "Higher education institutions - most prominently universities and colleges - have three functions in total. In addition to education, these are research and contributing to society. The research and education functions are two sides of a coin; research makes a higher level of education possible and education, in turn, develops the human resources to do researches. Recently, contributions to society have increasingly been demanded of higher education institutions. This means the higher education institutions need to have activities to ensure that accumulated knowledge is circulated directly back to society and that they do not become "ivory towers," All three functions are intimately connected and none can be separated out when considering higher education [2],"

San Beda College Manila is one of the private sectarian colleges in the Philippines. As a College it has proven its worth in the instruction function by producing quality graduates who topped the bar exams for lawyers, Certified Public Accountancy board exam, the medical Board exam and the Nursing Board exam. In response to the trilogy function mandated by CHED, the school has its Research Planning Knowledge Management Center (RPKMC) who constantly encourages and support faculty members to produce researches that are publishable. Likewise the extension arm/community involvement of the college is the Institutional Community Involvement Center (ICIC) who played great role in bringing instruction and research in community level. It was on school year 2013-2014 that ICIC grouped the faculty members and student organizations into different sectors, based on their expertise and objectives of the student organization. That is in that school year where Business Cluster Literacy Program (BCLP) and Health, Environment, Awareness liturgy and spirituality (HEALS) was formally opened to cater to the third function (community involvement) of the college.

The Department of Natural Sciences together with the Kapisanang Agham of San Beda (the professional student organization of the BS Human Biology) responded positively to the call of ICIC. Series of planning were done to actively participate in the program of ICIC. Thus the Health, Environment Awareness Lecture Caravan (HEALC) started. The aim of this lecture caravan is to increase level of awareness of people in the community especially partner communities of ICIC (with standing memorandum of agreement) in the aspect of health and environment. Also to help people in the community to gain access in the new programs of the government especially in environment like 
Project NOAH (Nationwide Operational Assessment of Hazards) and NDRRMC (National Disaster Risk Management Council). Moreover, increasing awareness and possible solutions on rural problems in health such as common diseases during typhoon and summer months, birth control methods and the use of indigenous herbal plants was also a prime goal of the lecture caravan.

This study identifies and categorizes activities done by HEALC along the trilogy function of San Beda.

It also determines the helpfulness of the Health, Environment Awareness Caravan (HEALC) implemented by the Department of Natural Sciences together with Kapisanang Agham ng San Beda in collaboration with the ICIC San Beda College to the beneficiaries which are the participants in the partner communities.

Likewise it embodies the identification of possible community-based researches for which the faculty members and students can conduct in order for the people in the community attain better quality of life as expressed in the mission of the school. "faith (fides),knowledge (scientia), virtue (virtus)and inculcate in them the Benedictine core values of prayer and work (ora et labora) that include, study, community, pursuit of peace [3].

\section{Methodology}

\section{A. Materials}

In the conduct of the lecture, the following were used; venue for the lecture, audience mostly housewives and village health workers which was organized by the ICIC of San Beda College. Flyer in local dialect (Tagalog version) was distributed after the lecture, audio-visual equipment, snacks and token for the participants and invited speaker.

To assess the degree of helpfulness of the lecture to the participants, a structured survey questionnaire was used. The questionnaire was translated in local dialect (Tagalog) and used four point Likert scale.

\section{B. Methods}

This study employed descriptive field survey-evaluative method and includes three phases. The descriptive part deals on identification and categorization of the activities done by the HEALC team based on the trilogy functions of the college (instruction, research and community involvement). The evaluative part was obtained by gathering and evaluating the perception of the participants on the usefulness of the lectures. The method in this study was patterned from several studies using self administered structured questionnaires to the respondents on their perception on the usability of seminars and lectures conducted [4]-[6].

The three phases on the implementation of the lecture caravan includes; first phase - Planning of HEALC, followed by conduct of the lectures and seminars. Participants' perceptions on the usefulness of the lecture were gathered through administration of structured questionnaire. Their responses were collated and third phase is the evaluation of the program which was based on the data gathered.

1) Planning of the health, environment awareness lecture caravan (HEALC)

\section{As follows;}

The Kapisanang Agham ng San Beda plan, prepare and submit activities to be implemented for school year to the Office of Prefect of Student Activities. Activity that exposes the students to the community is highly encouraged. This enables the students to hone their organizing skills, impart knowledge and result of their thesis in the community. This is done in close collaboration with the ICIC. Student Activity Budget Proposal was prepared and approved and it goes through the different channels to validate veracity and its congruency to the objective of the organization. These are the student council, the Office of the Prefect of the Student Activities and the Office of the Dean.

The Department of Natural Sciences mans the offering of BS Human Biology Program and supervises the activities of Kapisanang Agham ng San Beda. Professors in the Department are tasked to perform not only instruction, but research and community involvement as well. The HEALC is an excellent venue for the professors to share their expertise in Health and environment as well as the result of their researches to the partner communities of ICIC.

The ICIC of San Beda College collaborated with the partner communities for the participants' proper schedule and venue for the HEALC. It oversees the outreach activities of all sectors in the College.

\section{2) Partner community counterpart}

Months before the lecture the social worker from ICIC coordinates with the village secretary for the participants, venue and schedule of the Lecture.

\section{Data Gathered and Statistical Tools}

Data were gathered through documentary analysis of the activities done by the team and through the use of structured questionnaire using four point likert scale (4-very helpful, 3-helpful, 2- a little help, 1-not helpful) were given after the lecture except for the lectures in Be healthy-Be happy wherein the participants are minors and waste Segregation and Elderly Watch in which the participants are elderly with reading incapacity. Participants' answers were collated and result was presented using frequency counts and percentages.

Data gathered are the following;

1) Category of activities done by HEALC team from 2013 to January 2016 based on the threefold function of the college (Instruction, research and community involvement).

2) Participants' answers/evaluation on the degree of helpfulness of the activities done

3) Community-based researches identified

4) Other observations

\section{RESUlTS AND DISCUSSION}

\section{A. Activities Done by HEALC from 2013-January 2016, Its Categories Based on the Threefold Function of San Beda College}

In as much as HEALC only started on the second semester of school year 2013-2014, most of its activities was anchored in instruction and community involvement as displayed in Table I. Professors from the Department of Natural Sciences, 
invited experts and executive board of Kapisanang Agham ng San Beda shared their expertise in the topic/s assigned or requested by the community. The lectures under instruction and community involvement category are; Be Healthy-Be Happy, How to Cope-up during Flood, Disaster Mitigation and Preparedness, Diseases on Rainy Season, Natural Family Planning Methods, Diseases on Summer Season, Waste Segregation, and Elderly Watch.

Shift in the topics discussed was done in school year 2015-2016, wherein output of professor and students researches was imparted in the community where the research is applicable. With the constant visit of the HEALC team in Pulilan, Bulacan, it was observed that Siam weed and papaya were abundant in the locality. Thus, the team decided to conduct lecture/seminar on the use of these commodities which are product of professor and students' researches. The refereed research on Dried Siam Weed as Rice weevils' Eradicant is a published research of Dr. Liwayway Acero and is already in the data-based (Ebsco and google scholar). Likewise the study of Miss Marzha Ancheta $\left(4^{\text {th }}\right.$ year BS Human Biology student) and Dr. Liwayway Acero entitled Wound Healing Potential of Carica papaya Stem in Albino Rats was published in the International Journal of Biosciences, Biochemistry and Bioinformatics, volume 6, Nos. 1\&2, April 2016 and indexed by Proquest.

Indeed this lecture caravan proved to bridge the three functions of the college as eminent in the activities conducted.

\begin{tabular}{|c|c|c|c|}
\hline School Year & Title of Seminar/Lecture & Category & Partner community/village of ICIC \\
\hline $\begin{array}{l}2^{\text {nd }} \quad \text { semester } \\
2013-2014\end{array}$ & Be Healthy, Be Happy & Instruction and community Involvement & Brgy 637 San Miguel Manila \\
\hline 2014-2015 & $\begin{array}{l}\text { How to Cope Up during Flood } \\
\text { Disaster Mitigation and Preparedness } \\
\text { Diseases on Rainy Season } \\
\text { Natural Family Planning Methods } \\
\text { Diseases on Summer Season } \\
\text { Waste Segregation } \\
\text { Elderly Watch }\end{array}$ & $\begin{array}{l}\text { Instruction and community Involvement } \\
\text { Instruction and community Involvement } \\
\text { Instruction and community Involvement } \\
\text { Instruction and community Involvement } \\
\text { Instruction and community Involvement } \\
\text { Instruction and community Involvement } \\
\text { Instruction and community Involvement }\end{array}$ & $\begin{array}{l}\text { Pulilan Bulacan } \\
\text { Pulilan Bulacan and Taytay Rizal } \\
\text { Pulilan Bulacan } \\
\text { Pulilan Bulacan } \\
\text { Taytay Rizal } \\
\text { Pandacan, Manila } \\
\text { Pandacan, Manila } \\
\end{array}$ \\
\hline 2015-2016 & $\begin{array}{l}\text { Product of researches which was } \\
\text { presented in the international } \\
\text { conferences and are already published } \\
\text { in the data base. (EBSCO, Proquest } \\
\text { and google scholar). } \\
\text { Dried Siam weed as Rice Weevils' } \\
\text { Eradicant. } \\
\text { Wound Healing Potential Of } \\
\text { Carica papaya Stem in Albino Rats }\end{array}$ & Research and community involvement & Pulilan Bulacan \\
\hline
\end{tabular}

\section{B. Participants Evaluation on the Helpfulness of the Lecture on "How to Cope up During Flood"}

This lecture was done in Pulilan Bulacan. This partner community of ICIC San Beda Manila is frequently visited by flood. An invited speaker from Project NOAH (Nationwide Operational Assessment of Hazards was launched by the Department of Science and Technology. NOAH's mission is to undertake disaster science research, development, advance the use of cutting edge technologies and recommend innovative information services in government's disaster prevention and mitigation efforts. Though the use of science and technology and in partnership with the academe and other stakeholders, the DOST through Program NOAH is taking a multi-disciplinary approach in developing systems, tools, and other technologies that can be implemented by the government to help prevent and mitigate disasters [7]. The speaker discussed and explained the current flood mapping system done by Project Noah. She concluded that the village of Pulilan Bulacan is one of the catch basin of flood in Metro Manila Philippines. She suggested several ways on what village people should do in cases of flood in their area.

The evaluation of twenty five participants on the degree of helpfulness of the lecture revealed that; in terms of clarity of the lecture 92 percent of the respondents revealed that clarity is very helpful. Only $8 \%$ rated that is helpful since the lecture entailed internet use in searching for the flood map of the Philippines. All of the respondents evaluated the lecture is very timely since the lecture was done June of 2014 prior to rainy season. Ninety nine percent of the respondents evaluated that the flyer given is very helpful only one said helpful, since there is a tutorial in how to locate website of Project NOAH and it entails internet use. A study on Information Needs, Sources and Information Seeking Behaviour of Rural Women in Badagry, Lagos, Nigeria, obtained similar findings. According to the study the rural women do not have access to libraries as well as the local government. Organizing adult programs, sending Health workers to educate the rural women to ameliorate the situation is recommended [8]. The participants likewise requested for a seminar/lecture on disaster mitigation and preparedness for the next visit of HEALC team.

\section{Participants' Evaluation on the Helpfulness of the Lecture on Disaster Mitigation and Preparedness}

The HEALC team visited Pulilan Bulacan and Taytay Rizal for the seminar/lecture on Disaster Mitigation and Preparedness. Mr. Marino Deocariza from the National Disaster Risk Management Council of the Philippines was invited as the speaker. The lecture highlighted the 
vulnerability of the houses against disaster. He recommended some precautionary and mitigation measures on what shall be done in case of disasters like earthquake and fire. He explained Disaster Mitigation as embodied in the Philippine Disaster Risk Reduction and Management Act of 2010. Accordingly mitigation is the lessening or limitation of the adverse impacts of hazards and related disasters. Mitigation measures encompass engineering techniques and hazard-resistant construction as well as improved environmental policies and public awareness [9].

Total Participants in this lecture is fifty, from two villages, from Taytay Rizal twenty five (25) and Pulilan Bulacan also twenty five (25). One hundred percent of the participants claimed that the lecture is very clear, questions asked were all answered and the flyer is very helpful. Most of the respondents claimed that the lecture is timely done.

Participants in Pulilan Bulacan suggested lecture about Diseases on Flood Months (Mga Sakit sa Tagulan ) be given on the next visit of HEALC team.

\section{Participants' Evaluation on Helpfulness of the Lecture on "Diseases on Rainy Season"}

This lecture was done in Barangay Pulilan Bulacan. This partner community of ICIC San Beda Manila is frequently visited by flood. Prof. John Philipp Ramos a registered nurse and professor in the Department of Natural Sciences was the speaker for this lecture.

One hundred percent (25) of the participants agreed that the lecture is very useful in terms of clarity, lecture is timely done, helpfulness of the flyer given and helpfulness of the lecture. Ninety percent of the participants evaluated helpful on the answered questions since two participants questioned on the percentage of recovery in Leptospirosis. Prof. Ramos recommended that in case patient will feel symptoms of fever they should consult medical specialist rather than resort to self-medication. Self-medication is an alarming sign for society. It is a common practice in rural areas and even in India. Self medication with over the counter drugs may lead to adverse drug reactions, drug-drug interactions, skin problems, hypersensitivity reactions, allergy and even death [9]. Several studies show that self-medication is a global phenomenon. Self-medication can be prevented or minimized by increased awareness and education in society [10].

The participants likewise requested for a seminar/lecture on Birth control methods for the next visit of HEALC team.

\section{E. Participants' Evaluation on the Helpfulness of the Lecture on "Natural Birth Control Methods"}

San Beda College is a Catholic school wherein the value of Christianity is upheld. Thus the lecture specifically tackled Natural Birth control Methods such as the calendar method, Billings' method, abstinence and lactational amenorrhea method which is accepted by Catholic churches. This lecture was done in the village of Pulilan Bulacan where housewives of productive ages (able to give birth) served as the participants. Dr. Liwayway Acero, professor in the Department of Natural Sciences was the speaker for this lecture. Flyer in local dialect was given with a restriction that it shall be read only by the adults. The lecture was enriched by researches conducted in other countries like the study of on
Increasing Postpartum Contraception in Rural India Evaluation of a Community-Based Behavior Change Communication Intervention. In rural setting in India, about healthy pregnancy spacing, postpartum contraception to increase the interval between pregnancies, they emphasized the use of the lactational amenorrhea method. The intervention, which included in-service training, provision of job aids and educational materials, education of young couples and monitoring of the educational campaign, was feasible and effective [11]. One hundred percent (25) of the participants agreed that the lecture is very useful in terms of clarity, lecture is timely done, helpfulness of the flyer given and helpfulness of the lecture. Eighty eight percent of the participants evaluated helpful on the answered questions since three participants (12\%) questioned on the applicability of calendar method for women with irregular menstrual cycle. Dr. Acero advised that they should visit their OB-gynecologist to give them proper medication for the irregularity of their menstrual cycles.

\section{F. Participants' Evaluation on Helpfulness of the Lecture on "Diseases on Summer Season"}

This lecture was done in the village of Bagong Sikat in Taytay Rizal. Prof. John Philip Ramos a registered nurse and professor in the Department of Natural Sciences was the speaker for this lecture.

One hundred percent (25) of the participants agreed that the lecture is very clear, lecture is timely done, helpfulness of the flyer given and helpfulness of the lecture. Ninety four percent of the participants evaluated the seminar as helpful. One participant asked on the immunity of chicken pox during summer season if the person has chicken pox vaccine. Prof. Ramos reiterated that having a chicken pox vaccine is not $100 \%$ assurance that a person will not get infected with chicken pox. Recurrence of the disease for a person with chicken pox vaccine is an assurance that the degree of severity is milder compared with a person with no chicken pox vaccine.

\section{G. Participants' Evaluation on the Helpfulness of the Lecture on "Useful Herbal Plants in the Community"}

During the school year 2015-2016, HEALC focused on the result of the researches done in the Department of Natural Sciences, which is applicable in the partner community. The HEALC team decided to share the result of the researches on the published research of Acero L. in EBSCO and goggle scholar entitled "Dried Siam Weed as Rice Weevils' Eradicant" in Pulilan Bulacan since the community is known as rice producer in national Capital region and Siam weed commonly known as 'agonoi" or "hagonoy' is abundant in the area. Likewise the result of the research of Ancheta M. entitled "Wound Healing Property of Carica papaya Stem in Albino Rats" which was published in the International Journal of Bio-Sciences, Bio-engineering and Bio-informatics and indexed by proquest. Papaya grows wild in Pulilan Bulacan and its potential use as wound healing ointment is believed to be useful in the community

One hundred percent (25) of the participants agreed that the lecture is very clear, lecture is timely done, and the lecture is very helpful. Ninety four percent of the participants evaluated 
flyer as helpful, since one participant suggested that the flyer shall be printed in colored for them to clearly visualize pictures in the flyers.

\section{H. Community-Based Researches Identified, to Be Conducted to Prove Its Result and to Be Disseminated to the Partner Communities of ICIC-San Beda College, Manila}

With the constant visit of HEALC team in the partner communities, some community-based researches were identified as follows; In Pulilan Bulacan, one of the participants suggested a study on the wound healing potential of Siam Weed, Siam weed in the control of Bedbugs and other insects in the house. In Taytay Rizal, a study on Microbiological analysis of Water in Tungtung Falls was recommended. In Pandacan Manila, researches on growing vegetables on Pots and other researches about urban agriculture was identified.

Community-based researches identified in Pactil Mountain Province entitled Dried Garlic leaves in the control of Black whiskers mold in Mushroom Farm was identified. A good research prospects on the maximum use of carrot leaves was also recommended.

HEALC team is truly inspired not only to share their expertise to help people in the community, but also to learn from the traditional practices in the community which can be a source of potential community based research problem.

\section{Other Observations}

Villagers in the communities that the HEALC team constantly visits were so eager to learn new knowledge and techniques. They were able to value the use of common herbal plants in their village. They were able to gain access in the new programs of the government especially on how to cope up with calamities in their area. They realize that being healthy is also being wealthy.

The HEALC team, professors, speakers and students were motivated to plan out and conduct more lectures, seminar-workshops that will help people in the village. Both professors and teachers were able to span the learning environment rather than staying in the four corners of the classroom.

Indeed activities done by the HEALC team for the span of three years truly attest that participative teaching and learning is worthwhile, foster cooperation and promotes holistic outcome. A study on participatory action learning and action research, suggested that universities and funding organizations engaging in community-based research and development through partnerships, specifically in contexts of disadvantage, is a good approach to community development [12].

\section{CONCLUSION AND RECOMMENDATION}

Findings of this study revealed that the Health, Environment Awareness Lecture Caravan (HEALC) of the Department of Natural Sciences-San Beda College Manila proved to bridge the trilogy function of the college. The expertise of professors, students in the Department help people in the partner communities increase awareness on
Health and environment aspect as attested by the response of the participants in the lecture. Their expertise not only embodies the facts, knowledge and skills in the instruction but also in the research output that they disseminated in the villages/communities. The highly technical aspect of their expertise was transformed into the mind-set of the participants as based on the flyers translated in local dialect (Tagalog version) to be fully understood by people in the community. On the other hand, the HEALC team was able to generate possible community-based researches as suggested by the participants in the lectures and as what was observed by the team. The HEALC also manifested its compliance in the mandate of the Commission on Higher Education (CHED) and on the mission of the school

Follow-up studies should be explored on the usability of the research output disseminated in partner communities of ICIC San Beda College, Manila.

\section{ACKNOWLEDGMENT}

The author acknowledges her invaluable administrators, from San Beda College, College of Arts and Sciences. Dr. Tessie R. da Jose-Dean, Dr. Christian Bryan Bustamante-Vice Dean and Dr. Fedeliz S. Tuy-Associate-Vice Dean, for their constant encouragements. Special credit to Dr. James L. Piscos, the head of ICIC for his full support and trust given to the author. Heartfelt gratitude to the executive board of Kapisanang Agham ng San Beda from 2013-2016 for their courage and obedience. Ms. Angie Balance and Ms. Noriel Tabag for their unending support to the HEALC team.

\section{REFERENCES}

[1] J. Mahilum, "Determinants of research involvement, dissemination and utilization among the arts and sciences faculty in Southern Philippines," Liceo Journal of Higher Education Research Education Section, vol. 6, no. 2, p. 78, 2010.

[2] Japan International Cooperation. (2002). Overview of Higher Education: JICA Research. [Online]. Available: http://jica-rifrom.jica.go.jp/IFIC_and_JBICI-Studies/english/publicati ons/ reports/study /topical/approaches/pdf/higher_02.pdf

[3] San Beda College. (2013). Vision-Mission Statement. [Online] Available:

http://www.sanbeda.edu.ph/est1901/about_sbc-vissionmission.htm

[4] M. Shanoon, P. Dittus, and J. Epstein, "Family and community involvement in schools: Results from the school health policies and programs study 2006," Journal of School Health, vol. 77, no. 8] pp. 567-587, 2007.

[5] M. Sanders, "Community involvement in schools from concept to practice," Education and Urban Society, vol. 35, no. 2, pp. 161-180, 2003.

[6] J. Epstein, L. Joyce, M. Sanders, B. Simon, S. Beth, K. Salinas, J. Clark, N. Rodriguez; V. Voorhis, and L. Frances, "School, family, and community partnerships: Your handbook for action," 2002, p. 379.

[7] A. Lagmay, "Disseminating near real-time hazards information and flood maps in the Philippines through Web-GIS," DOST-Project NOAH Open-File Reports, vol. 1, no. 1, pp. 28-36, 2013.

[8] N. Ukachi, "Information needs, sources and information seeking behaviour of rural women in Badagry, Lagos, Nigeria," Information Trends, vol. 4, no. 5, pp. 23-24, 2007.

[9] DRR Knowledge Center. (2016). The Online Library for the Philippine Disaster Risk Reduction Center. [Online]. Available: http://drrknowledge.net/contact-page/

[10] S. Keshari, P. Kesarwani, and M. Mishra., "Prevalence and pattern of self-medication practices in rural area of Barabanki," Indian Journal of Clinical Practice, vol. 25, no. 7, pp. 11-12, 2014.

[11] M. Philip, E. Mohammed, K. Khan, K. Kumari, and R. Idnan, "Increasing postpartum contraception in rural India evaluation of a 
community-based behavior change communication intervention," International Perspectives on Sexual and Reproductive Health, vol. 38, no. 2, pp. 3-7, 2012.

[12] J. Kearney, L. Wood, and O. Zuber-Skerritt, "Community-university partnership: Using participatory action learning and action research (PALAR)," Gateways: International Journal of Community Research and Engagement, vol. 6, no. 1, p. 1, 2007.

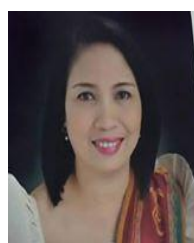

Liwayway H. Acero is a member of Asia Pacific Chemistry, Biology, Environment, Engineering Society, editorial member for Global Science and Technology Forum and Palawan Scientist. She is one of the Technical panels of the International Journal of Food Engineering and Technology. Educational background: doctor of education major in educational management from Palawan State University on March 2003. She conducted her dissertation at Okayama University Graduate School Education in Japan on March to June 2000 as research fellow. She got her DST Biology in 2009 from the University of the Philippines-Open University in Los Banos Laguna. She received her Master of Science degree in agricultural education-Plan Science (Agronomy) from the Western Philippines University in Aborlan, Palawan, Philippines on April 1993. She got her Bachelor of Science degree in Agriculture (cum laude), major in Animal science and minor in Plant Science (agronomy) from the Western Philippines University in Aborlan, Palawan Philippines on April 1986.

She is an associate professor and the chairperson of the Department of Natural Sciences, College of Arts \& Science in San Beda College, Mendiola, Manila, Philippines. Prior to her employment in San Beda College in Manila, she had served as professor for 20 years in Western Philippines University in Puerto Princesa City, Palawan, Philippines. She handled severa administrative works aside from teaching profession. She served as assistant dean of Western Philippines University, Puerto-Princesa Campus, Director for Instruction, Department Chairperson of the Education, Department chairperson of the Agribusiness Department \& chairperson for the thesis committee. She had 13 publications. Ten of her publications are international publications and can be found in the data-based system. Four are indexed by EBSCO and proquest and six are indexed by google scholar. 